\title{
The Polytrauma Patient at 34,000 Feet: The Safety of Fixed-Wing Transport
}

\author{
Ara Feinstein, Paula Ferrada, V Holland, GL Sandy, JA Diaz, Vafa Ghaemmaghami
}

\begin{abstract}
The safety of fixed-wing trauma transport in critically ill trauma patients; it is not well studied. The aim of the present manuscript is to evaluate the utility and safety of this transport method when used in sick trauma patients.
\end{abstract}

Methods: A retrospective cohort analysis of 100 consecutive trauma patients transferred by a single air ambulance company was conducted. Patient information was de-identified. All patients were transported using Lear 35a jets converted for medical use. Teams consisted of a combination of physicians, nurses, respiratory therapists and paramedics.

Results: A total of 67 patients, where transported via fixed-wing in the study period. The majority of patients had blunt trauma mechanism $(n=66)$. The majority of flights $(86.5 \%, n=59)$ were international. The mean flight time was 3 hours 4 minutes. Mean patient contact time was 6 hours 26 minutes. Average ISS was 22 . Twenty-seven percent $(n=18)$ were intubated, $13 \%(n$ $=9)$ were transfused in flight, $36 \%(n=24)$ had head injuries and $30 \%(n=20)$ had spine injuries. Strikingly, there were no mortalities or progression of neurologic deficits in transport.

Conclusion: Fixed-wing travel is a safe and underutilized resource in the transport of sick trauma patients.

Keywords: Prehospital air transport, International trauma transport.

How to cite this article: Feinstein A, Ferrada P, Holland V, Sandy GL, Diaz JA, Ghaemmaghami V. The Polytrauma Patient at 34,000 Feet: The Safety of Fixed-Wing Transport. Panam J Trauma Critical Care Emerg Surg 2012;1(1):12-14.

\section{Source of support: Nil}

Conflict of interest: None declared

\section{RESUMEN}

La seguridad del transporte de ala fija en pacientes politraumatizados, no está bien estudiada. El objetivo del presente manuscrito es evaluar la utilidad y seguridad de este método de transporte en pacientes politraumatizados.

Métodos: Se llevó a cabo un análisis retrospectivo de una cohorte de 100 pacientes politraumatizados transferidos por una compañía de ambulancia aérea. La información de los pacientes fue de-identificada para motivos de investigación. Todos los pacientes fueron transportados utilizando aviones Lear 35 bis convertidos para uso médico. El equipo de salud, consistió en una combinación de médicos, enfermeras, terapeutas respiratorios y personal paramédico.

Resultados: Un total de 67 pacientes fueron transportados a través de ala fija en el período del estudio. La mayoría de los pacientes tenían mecanismo de trauma cerrado $(n=66)$. La mayoría de los vuelos $(86.5 \%, \mathrm{n}=59)$ fueron internacionales. El tiempo de vuelo promedio fue de $3 \mathrm{~h} 4 \mathrm{~m}$. El tiempo medio de contacto con el paciente fue $6 \mathrm{~h} 26 \mathrm{~m}$. Promedio de ISS fue de $22.27 \%$ de los pacientes $(n=18)$ fueron intubados durante el transporte, $13 \%(n=9)$ fueron transfundidos en vuelo, $36 \%$ $(n=24)$ de pacientes tenían traumatismo cráneo-encefálico, y el
$30 \%(n=20)$ tenía lesiones de la columna. Sorprendentemente, no hubo mortalidades, ni progresión de los déficits neurológicos durante el transporte aéreo de ala fija.

Conclusiones: El transporte de ala fija es un recurso seguro y poco utilizado en el transporte de pacientes politraumatizados.

Palabras clave: Transporte aéreo del paciente politraumatizado, Transporte internacional de pacientes traumatizados.

\section{INTRODUCTION}

The Wright brothers documented the first flight of an airplane in 1903. In 1910. Gosman and Rhodes, both officers in the US Army, built an aircraft that was to function as the first air ambulance. ${ }^{1}$ Their test flight at Fort Barrancas, Florida flew only 500 yards at an altitude of 100 feet before crashing. ${ }^{2}$ This severely hampered military enthusiasm for air ambulance development until World War I. The first documented successful utilization of an air ambulance came during the retreat of the Serbian Army in 1915. Thirteen wounded or sick soldiers were safely transported 80 to 200 kilometers. $^{3}$ Civilian fixed wing transport followed in 1928, with the first established full time air ambulance service in the Australian that eventually became the royal flying doctor service. ${ }^{4}$ Modern fixed-wing civilian transport benefits from fast, reliable planes outfitted with intensive care unit technology.

Despite the advances, there are some physiological implications of aircraft travel that become more relevant in the injured patient. ${ }^{5}$ As altitude increases, the pressure exerted by the atmosphere decreases allowing the gas within a given space to expand. These changes in barometric pressure can cause affect several air spaces in the body, such as the tympanic membrane; causing rupture; in close spaces filled with air and fluid, such as the bowel causing over distention and also turning a simple pneumothorax into tension physiology. ${ }^{6}$

The safety of fixed-wing trauma transport in critically ill trauma patients it is not well studied. The aim of the present manuscript is to evaluate the utility and safety of fix wing transport in sick trauma patients.

\section{METHODS}

A retrospective cohort analysis of 100 consecutive trauma patients transferred by a single air ambulance company was conducted. Patient information was deidentified. All patients were transported using Lear 35a jets converted for medical use. Teams consisted of a combination of physicians, nurses, respiratory therapists and paramedics. 


\section{RESULTS}

Sixty-seven of these patients were ISS $>15$, indicating polytrauma. The majority of flights $(86.5 \%, \mathrm{n}=59)$ were international (Table 1). The mean flight time was 3 hours 4 minutes \pm 2 hours 41 minutes. Mean patient contact time was 6 hours 26 minutes \pm 3 hours 52 minutes. A sea-level cabin was required $31 \%(\mathrm{n}=21)$ of the flights. Average ISS was $22 \pm 16$. Twenty-seven percent $(\mathrm{n}=18)$ were intubated (Table 2), 13\% $(\mathrm{n}=9)$ were transfused in flight, 36\% $(\mathrm{n}=24)$ had head injuries and 30\% $(n=20)$ had spine injuries. The mechanism was largely blunt, with only one penetrating injury (Table 3 ). There were no mortalities or progression of neurologic deficits in transport.

\begin{tabular}{|lc}
\hline \multicolumn{2}{c}{ Table 1: Flight characteristics } \\
\hline Patient time & $6 \mathrm{hrs} 27 \mathrm{mins} \pm 3 \mathrm{hrs} 52 \mathrm{mins}$ \\
Transport time & $3 \mathrm{hrs} 21 \mathrm{mins} \pm 2 \mathrm{hrs} 41 \mathrm{mins}$ \\
Refueling stops & $0.49 \pm 0.73$ \\
Maximum air speed (Mach) & $0.77 \pm 0.01$ \\
Maximum altitude & $34134 \pm 6943$ \\
Sea level cabin & $\mathrm{N}=21(31.3 \%)$
\end{tabular}

\begin{tabular}{ll}
\hline \multicolumn{2}{c}{ Table 2: Patient demographics } \\
\hline Age & $46.3 \pm 21.4$ \\
Male (\%) & 58.3 \\
ISS & $28.6 \pm 15.9$ \\
Intubated & $\mathrm{N}=18(26.9 \%)$ \\
Transfused & $\mathrm{N}=9(13.4 \%)$ \\
Blunt trauma & $\mathrm{N}=66(98.5 \%)$ \\
Head injury & $\mathrm{N}=24(35.8 \%)$ \\
Spine injury & $\mathrm{N}=20(29.8 \%)$ \\
Transport mortality & $\mathrm{N}=0(0 \%)$
\end{tabular}

\begin{tabular}{ll}
\multicolumn{3}{c}{ Table 3: Mechanism of injury } \\
\hline Fall & $\mathrm{N}=21(31.3 \%)$ \\
MVC & $\mathrm{N}=18(26.9 \%)$ \\
Watersports & $\mathrm{N}=8(11.9 \%)$ \\
Other & $\mathrm{N}=8(11.9 \%)$ \\
MCC & $\mathrm{N}=5(7.5 \%)$ \\
Bicycle & $\mathrm{N}=3(4.5 \%)$ \\
Pedestrian & $\mathrm{N}=2(3.0 \%)$ \\
Blunt assault & $\mathrm{N}=1(1.5 \%)$ \\
Stab & $\mathrm{N}=1(1.5 \%)$
\end{tabular}

\section{DISCUSSION}

This study demonstrates that severely injured trauma patients can be transported safely over long distances by fixed-wing air ambulances.

The concept that definitive trauma care must be initiated within a 60 -minute window (the golden hour) has been taught, and practiced for several decades. ${ }^{7}$ Several studies have shown that increased total out-of-hospital time is associated with higher mortality among seriously injured trauma patients. ${ }^{8-11}$ This is especially true in rural trauma patients with long emergency medical services response times. ${ }^{12}$ In this and other studies, air transport is faster and in some occasion the only route of transport for critically ill trauma patients. ${ }^{13-15}$

Despite being well outside the golden hour with significant injuries, the patients in the study did not suffer adverse events due to transport. This may be explained by several factors. Firstly, the patient had often been stabilized by the time the air ambulance crews arrived. The time to arrange international flights as well as the transport time to the patient selects for patients that have survived their injuries, even if they have not received definitive care.

Secondly, the level of care provided in flight may have been beneficial. The transport team consists of a trauma surgeon and/or a critical care nurse, significantly increasing the level of care compared to normal transport. Advanced treatments are available, such as ventilators, blood and hemodynamic monitors. The transport environment is more similar to an ICU than an ambulance. This is consistent with previous studies that have shown that providing high level of care en route can provide a temporary solution for early resuscitation. ${ }^{16}$ In fact aeromedical treatment has been shown to improve patient outcome, even in patients severely injured. ${ }^{17}$

Finally, the speed at which these patients were transported is also an important factor in the results. In the setting of trauma patients that are unstable and in need of definitive care, faster is always better. The Lear 35A aircraft utilized in the study are fixed-wing, pressurized jet aircraft that can achieve speeds of 530 miles per hour (mph). A fully dedicated single-engine turbine helicopter average speed is only $115 \mathrm{mph}$. In the present article, most fixed-wing flights were international with the average transport time of just 3 hours.

The current study is limited by the retrospective data collection. In the future, a prospective study might help to better elucidate the benefits of fixed-wing trauma transport. Only one patient in the study suffered a penetrating injury, thus making it difficult to make conclusions about these mechanisms. The cost of each flight was not obtained, although it must be acknowledged that like many beneficial treatments in medicine, they were significant. The vast majority of patients had travel insurance or their home government paid for the transport. In most cases, there was no alternative to allow the patient to travel the required distance. Still, prior studies show that fixed-wing transport is associated with less cost per mile than rotary. ${ }^{18}$ 


\section{SUMMARY}

This article supports the use of fixed-wing flights transport for trauma patients. Severely injured polytrauma patients requiring ongoing resuscitation and mechanical ventilation were safely transported over long distances. Patients with head and spine injuries did not have adverse neurologic events in transport. Fixed-wing transport may be an underutilized resource in trauma systems and these findings may have implications for rural trauma patients.

\section{REFERENCES}

1. Hurd W, Jernigan JG. Aeromedical evacuation: Management of acute and stabilized patients. Springer 2002.

2. Caroline NL. Nancy Caroline's emergency care in the streets. Jones \& Bartlett Publishers (6th ed) 2007.

3. Lynch C, Weed FW, McAfee L. The medical department of the United States Army in the World War (The official history series for World War I). Washington: US Army Surgeon General's Office, 1923-29. http://history.amedd.army.mil/booksdocs/wwi/ seriesbklst.htm. Accessed October 1, 2011.

4. The Royal Flying Doctor Service. http://en.wikipedia.org/wiki/ Royal Flying Doctor_Service. Accessed October 10, 2011.

5. Woodward GA, Vernon DD. Aviation physiology in pediatric transport. In: Jaimovich DG, Vidyasagar D (Eds). Pediatric and Neonatal Transport Medicine (2nd ed) Philadelphia, PA: Hanley \& Belfus Inc 2002;2:43-54.

6. Bossley C, Balfour-Lynn IM. Taking young children on aeroplanes: What are the risks? Arch Dis Child 2008;93:528-33.

7. Lerner EB, Moscati RM. The golden hour: Scientific fact or medical 'urban legend'? Acad Emerg Med 2001;8:758-60.

8. Feero S, Hedges JR, Simmons E, et al. Does out-of-hospital EMS time affect trauma survival? Am J Emerg Med 1995;13:133-35.

9. Gervin AS, Fischer RP. The importance of prompt transport in salvage of patients with penetrating heart wounds. J Trauma 1982;22:443-46.

10. Ivatury RR, Nallathambi MN, Roberge RJ, et al. Penetrating thoracic injuries: In-field stabilization versus prompt transport J Trauma 1987;27:1066-72.

11. Clevenger FW, Yarborough DR, Reines HD. Resuscitative thoracotomy: The effect of field time on outcome. J Trauma. 1988;28:441-45.

12. Grossman DC, Kim A, MacDonald SC, et al. Urban-rural differences in prehospital care of major trauma. J Trauma 1997;42:723-29.

13. Wills VL, Eno L, Walker C. Use of an ambulance-based helicopter retrieval service. Aust N Z J Surg 2000;70:506-10. DOI: $10.1046 /$ j.1440-1622.2000.01893.
14. Cameron PA. Helicopter transport: Can physicians save lives? Aust N Z J Surg 1999;69:690-91.

15. Krüger AJ, Skogvoll E, Castrèn M, Kurola J, Lossius HM. Scandinavian pre-hospital physician-manned Emergency Medical Services - same concept across borders? Resuscitation 2010;81(4):427-33.

16. Baxt WG, Moody P. The impact of rotorcraft aeromedical emergency care service on trauma mortality. JAMA 1983;249:3047-51. DOI: 10.1001/jama.249.22.3047.

17. Thomas F, Wisham J, Clemmer TP, Orme JF Jr, Larsen Kg. Outcome, transport times, and costs of patients evacuated by helicopter versus fixed-wing aircraft. West J Med 1990 Jul;153(1):40-43.

18. Mitchell AD, Tallon JM, Sealy B. Air versus ground transport of major trauma patients to a tertiary trauma centre: A province wide comparison using TRISS analysis. Can J Surg 2007;50:129-33.

\section{ABOUT THE AUTHORS}

\section{Ara Feinstein (Corresponding Author)}

Assistant Professor, Department of Surgery, Division of Trauma and Surgical Critical Care, Banner Good Samaritan Medical Center, 925 E McDowell Rd, Phoenix, AZ 85006, USA, e-mail: ara.Feinstein@bannerhealth.com

\section{Paula Ferrada}

Assistant Professor, Department of Surgery, Division of Trauma and Critical Care, Virginia Commonwealth University, West Hospital, VA, USA

\section{Holland}

National Air Ambulance, Lauderdale, FL, USA

\section{GL Sandy}

National Air Ambulance, Lauderdale, FL, USA

\section{JA Diaz}

National Air Ambulance, Lauderdale, FL, USA

\section{Vafa Ghaemmaghami}

Assistant Professor, Department of Surgery, Division of Trauma and Surgical Critical Care, Banner Good Samaritan Medical Center, AZ USA 